\title{
EQUATION FOR EATING DISORDER RISK BEHAVIORS IN FEMALE ATHLETES
}

\author{
EQUAÇÃO PARA OS COMPORTAMENTOS DERISCO DE TRANSTORNOS ALIMENTARES EM ATLETAS
}

EQUACIÓN PARA LOS COMPORTAMIENTOS DE RIESGO DE TRASTORNOS ALIMENTARIOS EN ATLETAS

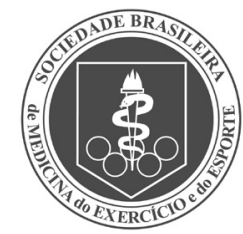

Original Article

ARTIGO ORIGINAL Artículo Original

\begin{abstract}
Leonardo de Sousa Fortes' ${ }^{1}$ (ID (Physical Education Professional) Maria Elisa Caputo Ferreira² (D) (Physical Education Professional) Saulo Melo Fernandes de Oliveira $^{3}$ (ID (Physical Education Professional)

Lenamar Fiorese ${ }^{4}$ (D) (Psychologist)

Sebastião Sousa Almeida ${ }^{5}$ (ID (Psychologist)
\end{abstract}

1. Universidade Federal da Paraíba, Department of Physical Education, Center for Health Sciences, João Pessoa, PB, Brazil.

2. Universidade Federal de Juiz de Fora (UFJF), Master's Degree Program in Physical Education, Juiz de Fora, MG, Brazil.

3. Universidade Federal de Pernambuco, Department of Physical Education, Center for Physical Education and Sports Sciences, Academic Center of Vitória, Vitória de Santo Antão, Pernambuco, Brazil. 4. Universidade Estadual de Maringá, Department of Physical Education, Maringá, PR, Brazil. 5. Universidade de São Paulo, Faculty of Philosophy, Sciences, and Language and Literature, Department of Psychology, Laboratory for Nutrition and Behavior, São Paulo, SP, Brazil.

\section{Correspondence:}

Leonardo de Sousa Fortes. Rua Clovis Bevilaqua, 163/1003, Madalena, Recife, PE, Brazil. 50710330.

leodesousafortes@hotmail.com

\begin{abstract}
Introduction: It is difficult to detect athletes at risk of eating disorders. Objective: The aim of this study was to create a predictive equation for eating disorder risk behaviors (EDRB) in female athletes. Methods: 484 athletes participated in the study. The Eating Attitudes Test (EAT-26) was used to assess EDRB. The Sociocultural Attitudes Towards Appearance Questionnaire-3 was used to analyze the sociocultural influence on body image. The Body Shape Questionnaire and the Body Checking and Avoidance Questionnaire were used to assess body dissatisfaction in relation to thinness, and body checking, respectively. Skinfold thickness, body weight and height were also measured. The demographic data collected were age and weekly training regime. Results: The findings indicate that body mass index (BMI), body fat percentage (BF\%), sociocultural influence, body checking and body dissatisfaction in relation to thinness explain 23\% of the EDRB variance $(p=0.001)$. The results showed no difference between the EAT-26 scores and the predictive equation $(p=0.27)$. Conclusion: It was concluded that the predictive equation is reliable for evaluating EDRB in female athletes. Level of evidence III; study case-control.
\end{abstract}

Keywords: Sports; Feeding and eating disorders; Athletes.

\section{RESUMO}

Introdução: Destaca-se a dificuldade de rastrear atletas com risco de desencadeamento de transtorno alimentar. Objetivo: O objetivo do presente estudo foi criar uma equação preditiva de comportamentos de risco para os transtornos alimentares (CRTA) para atletas do sexo feminino. Métodos: Participaram 484 atletas. O Eating Attitudes Test (EAT-26) foi usado para avaliar os CRTAs. O Sociocultural Attitudes Towards Appearance Questionnaire-3 foi usado para analisar a influência sociocultural na imagem corporal. Foram usados o Body Shape Questionnaire e o Body Checking and Avoidance Questionnaire para avaliar insatisfação corporal direcionada para a magreza e checagem corporal, respectivamente. Foram medidas dobras cutâneas, massa corporal e estatura. Os dados demográficos coletados foram idade e regime semanal de treino. Resultados: Os achados indicaram que índice de massa corporal (IMC), percentual de gordura (\%G), influência sociocultural, checagem corporal e insatisfação corporal direcionada para a magreza explicaram $23 \%$ da variância dos CRTA $(p=0,001)$. Os resultados não demonstraram diferença entre os escores do EAT-26 e da equação preditiva $(p=0,27)$. Conclusão: Concluiu-se que a equação preditiva é fidedigna para avaliar o CRTA em atletas do sexo feminino. Nível de evidência III; Estudo de caso-controle.

Descritores: Esportes; Transtornos da alimentação e da ingestão de alimentos; Atletas.

\section{RESUMEN}

Introducción: Se destaca la dificultad de rastrear atletas con riesgo de desencadenamiento de trastorno alimentario. Objetivo: El objetivo del presente estudio fue crear una ecuación predictiva de comportamientos de riesgo para los trastornos alimentarios (CRTA). Métodos: Participaron 484 atletas. Fue usado el Eating Attitudes Tests (EAT-26) para evaluar los CRTAs. Fue usado el Sociocultural Attitudes Towards Appearance Questionnaire-3 para analizar la influencia sociocultural en la imagen corporal. Fueron usados el Body Shape Questionnaire y el Body Checking and Avoidance Questionnaire para evaluar insatisfacción corporal direccionada a delgadez y verificación corporal, respectivamente. Fueron medidos pliegues cutáneos, masa corporal y estatura. Los datos demográficos colectados fueron edad y régimen semanal de entrenamiento. Resultados: Los hallazgos indicaron que índice de masa corporal (IMC), porcentual de grasa (\%G), influencia sociocultural, verificación corporal e insatisfacción corporal direccionada para la delgadez explicaron $23 \%$ de la variancia de los CRTA $(p=0,001)$. LOS resultados no demostraron diferencia entre los puntajes del EAT-26 y de la ecuación predictiva $(p=0,27)$. Conclusión: Se concluye que la ecuación predictiva es fidedigna para evaluar el CRTA en atletas del sexo femenino. Nivel de evidencia III; Estudio de Caso-control.

Descriptores: Deportes; Trastornos de alimentación y de la ingestión de alimentos; Atletas. 


\section{INTRODUCTION}

Eating restrictions for long periods, self-inducing vomiting, use of laxatives/diuretics and strenuous physical exercise for the purpose of "burning calories" are considered risk behaviors for eating disorders." Studies indicate that approximately $30 \%$ of female athletes adopt risk behaviors for eating disorders with the premise of reducing body weight to optimize sports performance. ${ }^{2-5}$ However, it appears that risk behaviors for eating disorders have an inversely proportional relationship with sports performance., ${ }^{1,6}$

Although scientific investigations in the sports field show a prevalence of $30 \%$ of risk behaviors for eating disorders in female athletes, 2,3,5 researchers emphasize that this prevalence may be even higher due to their omission regarding such behaviors. ${ }^{7}$ According to Fortes et al., ${ }^{8}$ due to fear of being cut from the main team, athletes can offer false answers in subjective tools that seek to track risk behaviors for eating disorders. Therefore, it is extremely important to develop a new method that can indicate athletes who are vulnerable to eating disorders without them knowing that they are being screened for such psychiatric syndromes. In this sense, creating an equation which includes factors associated with risk behaviors for eating disorders may be feasible to analyze whether female athletes are vulnerable to such behaviors.

The scientific literature has pointed out personal (body dissatisfaction and drive for thinness and body checking), 3,9 morphological (body fat percentage and body mass index) ${ }^{5}$ and demographic (age and weekly training regime) ${ }^{10}$ variables as predictors of health risk behaviors for eating disorders in female athletes. Thus, the aim of this study was to create a predictive equation of risk behaviors for eating disorders, using body dissatisfaction and drive for thinness, body checking, body fat percentage (\% F), body mass index (BMI), age and weekly training regime as predictors.

\section{MATERIALS AND METHODS}

\section{Ethical considerations}

This study was approved by the Human Research Ethics Committee (CAAE - 05166712.8.0000.5407). The guardians (in the case of athletes under 18 years old) signed an Informed Consent Form (ICF), which explained the objectives and procedures of the study. All athletes (minors and over 18 years old) signed the Assent Form, agreeing with their voluntary participation in the investigation. Participants were guaranteed anonymity and total confidentiality in the data treatment.

\section{Participants}

The population consisted of Brazilian female athletes, aged 12 years or over. The following inclusion criteria were adopted: a) present the ICF signed by the guardian (if she was under 18) and sign the Assent Form; b) systematically train her respective modality with a minimum training regime of six hours per week (minimum frequency of three days per week and duration of two hours/training, or frequency of six days per week and duration of one hour/training); c) have minimal participation in a regional competition in 2014 and; d) be available to answer questionnaires and participate in anthropometric assessments. In addition, the following exclusion criteria were adopted: a) present a physical or intellectual disability (indicated by the trainer) and; b) use psychoactive medications in the last six months (indicated by the athlete himself).

It was possible to include 556 female athletes in the study. However, 72 athletes were excluded for not answering the questionnaires in their entirety and/or not participating in the anthropometry measurement, and the final sample was composed of 484 athletes [Athletics $(n=8)$, Basketball ( $n=34)$, Boxing $(n=6)$, Cycling ( $n=11)$, Football $(n=36)$, Artistic Gymnastics ( $n=28)$, Rhythmic Gymnastics $(n=11)$, Handball $(n=33)$,
Jiu-Jitsu ( $n=26$ ), Judo ( $n=30)$, Synchronized Swimming $(n=38)$, Swimming ( $n=84)$, Figure Skating $(n=17)$, Water Pole $(n=15)$, Rowing $(n=6)$, Diving $(n=4)$, Surf $(n=10)$, Tae-kwon-do $(n=7)$, Tennis $(n=8)$, Triathlon ( $n=4)$, Sailing $(n=3)$, Volleyball $(n=57)$ and Beach Volleyball $(n=8)$ ], linked to clubs in eight Brazilian states (Ceará, Minas Gerais, Paraíba, Pernambuco, Paraná, Rio de Janeiro, Rio Grande do Sul and São Paulo). A summary (flowchart) of the sample recruitment can be seen in Figure 1.

\section{Instruments}

\section{Eating Attitudes Test (EAT-26)}

EAT-26 was applied to assess the risk behavior for eating disorders. The questionnaire consists of 26 questions divided into three sub-scales: 1) diet - refers to the pathological refusal of foods with a high caloric content and concern about physical appearance; 2) bulimia and concern about food - refers to episodes of binge eating, followed by purgative behaviors for loss/control of body weight and; 3 ) oral self-control - reflects self-control in relation to food and assesses the environmental and social forces that stimulate food intake. EAT-26 final score is given by the sum of its items. There are six answer options ranging from 0 to 3 points (always $=3$, usually $=2$, often $=1$, sometimes $=0$, rarely $=0$ and never $=0$ ). The version used was validated for the Brazilian population, ${ }^{11}$ presenting a 0.82 internal consistency analysis. For the present study, Cronbach's alpha of 0.89 was found.

\section{Body Shape Questionnaire (BSQ)}

BSQ was applied to assess body dissatisfaction and drive for thinness. It is a self-assessment test with 34 questions that seek to assess the subjects' concern about their weight and body shape. The version used for subjects aged 18 years and younger was validated for Brazilian adolescents, ${ }^{12}$ and its internal consistency analysis revealed a 0.96 a for both sexes and a significant correlation coefficient between test-retest scores. The version used for athletes over 18 years old was validated for the young Brazilian population. ${ }^{13} \mathrm{BSQ}$ score is given by the sum of its items. The higher the score, the greater the dissatisfaction with the body. It should be noted that the items in BSQ versions for adults and adolescents are identical. For the sample of this study, Cronbach's alpha of 0.95 was identified.

\section{Body Checking and Avoidance Questionnaire (BCAQ)}

BCAQ assessed body checking behaviors. BCAQ consists of 22 items, subdivided into 5 sub-scales, namely: 1) tweak - reflects the frequency with which subjects evaluated "tweak" themselves to check or highlight

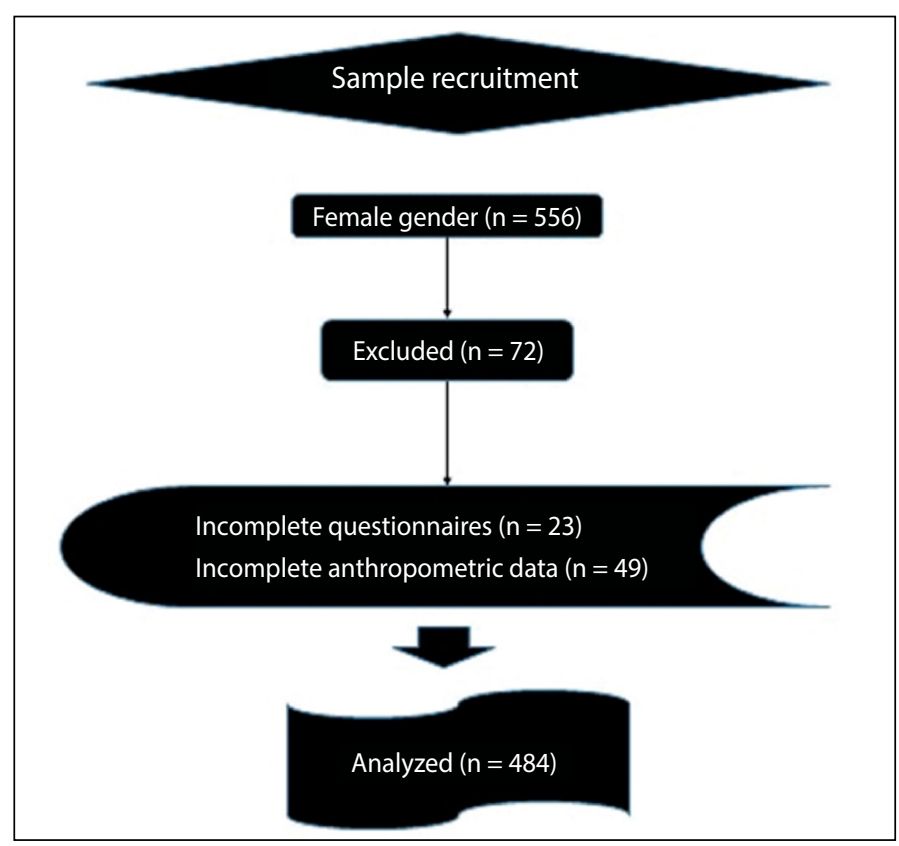

Figure 1. Flowchart of sample recruitment. 
parts of the body; 2) use of mirror - refers to the frequency with which subjects look in the mirror to check some part of the body; 3 ) palpation - refers to the frequency that subjects feel or touch parts of the body in order to identify body saliences; 4) use of measuring tape - indicates the frequency of using measuring tape to check the size of the perimeters of body parts; 5) self-weighing and social comparisons - reflects the frequency with which subjects weigh themselves and/or compare themselves with other women. BCAQ was validated for the young Brazilian female population and showed good psychometric properties. ${ }^{14}$ For this sample, internal consistency was calculated, represented by Cronbach's alpha of 0.93 .

\section{Sociocultural Attitudes Towards Appearance Questionnaire-3 (SATAQ-3)}

In order to assess the internalization of the ideal of thinness, the athletes answered SATAQ-3. This tool is scored on a Likert scale with five response options ("Strongly disagree" to "Strongly agree"). SATAQ-3 total score is calculated by the sum of the answers, with the highest score representing a greater influence of socio-cultural aspects on body image. The questionnaire consists of 30 questions designed to assess the general internalization of socially established standards (nine items), including the ideal athletic body (five items), the pressure exerted by these standards (seven items), and the media as a source of information about appearance (nine items). SATAQ-3 version used in this study was translated and adapted to the young Brazilian population, with its internal consistency established for this population. ${ }^{15}$ For this sample, the internal consistency was calculated by Cronbach's alpha, obtaining a satisfactory value of 0.86 .

\section{Anthropometry}

To calculate the percentage of body fat (\% F), a LANGE ${ }^{\oplus}$ adipometer (Cambridge Scientific Industries Inc.) was used, with an accuracy of 1 $\mathrm{mm}$, in order to verify the thickness of the skinfolds. The procedures for the collection of skinfolds were performed according to the standards determined by the International Society for Advancement for Kineanthropometry. ${ }^{16}$ The literature recommends that there should be no differences greater than $10 \%$ between one measurement and the others in the same place, ${ }^{17}$ therefore, the calculation of the technical error of measurement (TEM) proposed by Silva et al., ${ }^{17}$ was performed excluding data with variance greater than $10 \%$.

The $\% \mathrm{~F}$ was estimated by the doubly indirect method, using the equation developed by Siri. ${ }^{18}$ For the calculation of body density, the protocols of Slaughter et al. ${ }^{19}$ were used [considering ethnicity and maturation stage according to chronological age (pubescent - 12 to 14 years old, and post-pubescent - 15 to 17 years old)], and Jackson, Pollock and Ward, ${ }^{20}$ created for adolescents and adult females, respectively. Triceps and subscapular skinfolds were measured in athletes under 18 years old. In athletes aged 18 years or older, tricipital, suprailiac and abdominal skinfolds were measured. These measurements were taken in a rotational manner and collected three times, considering the mean of the values. It should be noted that no skinfold datum was excluded due to ETM, since all variances were less than $5 \%$ for all athletes.

Body mass was measured using a Tanita ${ }^{\circledR}$ portable digital scale (São Paulo, SP, Brazil) with $0.1 \mathrm{~kg}$ accuracy and a maximum capacity of $220 \mathrm{~kg}$. A Tonelli ${ }^{\circledR}$ portable stadiometer (São Paulo, SP, Brazil) with a precision of $0.1 \mathrm{~cm}$ and a maximum height of $2.20 \mathrm{~m}$ was used to measure athletes' height. The body mass index (BMI) was obtained using the calculation:

$$
\mathrm{BMI}=\text { body mass }(\mathrm{kg}) / \text { height }\left(\mathrm{m}^{2}\right) \text {. }
$$

\section{Demographic data}

Demographic data [age and weekly training regime (weekly frequency $x$ daily hours)] were collected by means of a questionnaire created by the researchers.

\section{Procedures}

The coaches of several teams of diverse sports were sought to explain the procedures, as well as the objectives of the study. After coaches' consent, a meeting was arranged with each team to talk to the athletes and explain all the ethical procedures of the research.

The study was divided into two moments: The first was intended for the application of EAT-26, BSQ, BCAQ and SATAQ-3 questionnaires. It is worth mentioning, above all, that only one researcher was responsible for their application. This precaution was taken so that there were no differences in explanations and influence from other researchers on the responses to self-administered questionnaires.

During the collections, the athletes received the same verbal guidance, and written guidance on appropriate procedures was also present in the questionnaires. There was no communication between the study subjects. The questionnaires were distributed at the moment the athletes entered the room, and filling them out was configured as a voluntary character. There was no time limit for filling them out.

In the second stage, which was carried out immediately after completing the questionnaires, anthropometric measurements (body mass, height and skinfolds) were performed. The clubs that participated in the research provided adequate rooms for the evaluations. The measurements were performed individually in the environment to avoid interference from teammates.

These procedures were carried out in clubs and/or competitive events in 11 cities in eight Brazilian states, during the ten-month period, until the desired sample was reached.

\section{Statistical analysis}

Kolmogorov-Smirnov test was conducted to assess data distribution. Due to the result of this test for EAT-26 scores, parametric techniques were chosen. Therefore, Pearson's correlation was used to analyze the relationship between the independent variables ( $B S Q$, BCAQ, SATAQ-3, \% F, BMI and demographic data) with EAT-26 scores. Then, the backward method was used to create the formula for predicting risk behaviors for eating disorders (EAT-26 score), inserting in the model only variables that demonstrated $r \geq 0.30$ with a $5 \%$ significance. In this sense, the following blocks were conducted: 1) BMI; 2) \% F; 3) sociocultural influence (SATAQ-3); 4) body check (BCAQ), and 5) body dissatisfaction drive for thinness (BSQ). Finally, the dependent Student's t test was used to compare EAT-26 scores and the scores obtained by the predictive equation. This analysis was conducted with the purpose of evaluating the predictive equation validity. The data treatment was carried out using SPSS 21.0 software, with a $5 \%$ significance level.

\section{RESULTS}

The athletes' demographic characteristics in this study can be seen in Table 1.Table 2 shows the correlations between the study variables. The findings showed no statistically significant relationship between age and EAT-26 $(r=0.11, p=0.08)$, nor between training regime and EAT-26 $(r=0.02, p=0.76)$. In contrast, BMI $(r=0.36, p=0.007), \% F(r=0.38$, $p=0.003)$, sociocultural influence $(r=0.54, p=0.001)$, body checking $(r=0,38, p=0.002)$, and body dissatisfaction and drive for thinness $(r=0.66, p=0.001)$ demonstrated a statistically significant relationship with risk behavior for eating disorders. 
Table 1. Demographic characteristics of the athletes participating in the study.

\begin{tabular}{|c|c|c|}
\hline Variable & Mean (SD) & Min - Max \\
\hline Age (years) & $17.11(1.55)$ & $12.00(36.00)$ \\
\hline Practice time (years) & $8.76(2.33)$ & $3.00(24.00)$ \\
\hline Weekly training regime (hours) & $12.71(2.89)$ & $6.00(36.00)$ \\
\hline Fat percentage & $21.60(4.48)$ & $9.23(32.45)$ \\
\hline \multirow[t]{2}{*}{ Body mass index $\left(\mathrm{kg} / \mathrm{m}^{2}\right)$} & $22.97(1.32)$ & $15.29(30.10)$ \\
\hline & $\mathrm{N}$ & $\%$ \\
\hline \multicolumn{3}{|l|}{ Age group } \\
\hline $12-18$ & 262 & 54 \\
\hline $18-25$ & 145 & 30 \\
\hline$>25$ & 77 & 16 \\
\hline \multicolumn{3}{|l|}{ Competition level } \\
\hline Regional & 93 & 19 \\
\hline State & 160 & 33 \\
\hline National & 104 & 22 \\
\hline International & 127 & 26 \\
\hline \multicolumn{3}{|l|}{ Race } \\
\hline White & 288 & 60 \\
\hline Black & 81 & 16 \\
\hline Asian & 44 & 9 \\
\hline Brown & 71 & 15 \\
\hline
\end{tabular}

$\overline{\mathrm{SD}}=$ standard deviation; Min = Minimum; Max = Maximum; $\mathrm{N}$ = absolute sample size; $\%$ = relative sample size

Table 2. Correlations between research variables.

\begin{tabular}{c|c|c|c|c|c|c|c|c}
\hline Variable & EAT-26 & Age & TR & BMI & \%F & SATAQ-3 & BCAQ & BSQ \\
\hline EAT-26 & - & 0.11 & 0.02 & $0.36^{*}$ & $0.38^{*}$ & $0.54^{*}$ & $0.38^{*}$ & $0.66^{*}$ \\
\hline Age & & - & $0.32^{*}$ & 0.07 & 0.05 & $0.17^{*}$ & 0.06 & $0.13^{*}$ \\
\hline TR & & & - & 0.06 & $-0.20^{*}$ & 0.07 & -0.04 & 0.07 \\
\hline BMl & & & & - & $0.52^{*}$ & 0.10 & 0.08 & $0.20^{*}$ \\
\hline \%F & & & & & - & 0.10 & $0.17^{*}$ & $0.29^{*}$ \\
\hline SATAQ-3 & & & & & & - & $0.20^{*}$ & $0.40^{*}$ \\
\hline BCAQ & & & & & & & - & $0.40^{*}$ \\
\hline BSQ & & & & & & & & - \\
\hline
\end{tabular}

Note: $\mathrm{TR}=$ Training regime, $\mathrm{BMI}=$ Body mass index, $\% \mathrm{~F}$ = fat percentage, SATAQ-3 = Sociocultural Attitudes Towards Appearance Questionnaire-3, BCAQ = Body Checking and Avoidance Questionnaire, BSQ = Body Shape Questionnaire, ${ }^{*} p \leq 0.05$.

Concerning the multiple regression model, the results indicated that BMI,\% F, sociocultural influence, body checking and body dissatisfaction and drive for thinness explained $43 \%$ of the variance of risk behaviors for eating disorders $\left(F(5,479)=15,05, R^{2}=0.43, p=0.001\right)$. In addition, it was possible to construct the following equation from the backward method findings:

$$
\begin{gathered}
\text { EAT-26 (score })=-5.013+(0.121 \times \mathrm{BMI})+(0.115 \times \% \mathrm{G})+ \\
(0.102 \times \text { SATAQ-3) }-(0.013 \times \mathrm{BCAQ})+(0.141 \times \mathrm{BSQ})
\end{gathered}
$$

Note. BMI = Body mass index $\left(\mathrm{kg} / \mathrm{m}^{2}\right), \% \mathrm{G}=$ Body fat percentage, SATAQ-3 = Sociocultural Attitudes Towards Appearance Questionnaire-3 score, BCAQ = Body Checking and Avoidance Questionnaire score, BSQ = Body Shape score Questionnaire.

Regarding the comparison of EAT-26 scores to the predictive equation scores, the findings showed no difference $(F(2,482)=1.83, \mathrm{t}=$ 1.03, $p=0.27$ ).

\section{DISCUSSION}

The research was based on the premise of building a predictive equation of risk behaviors for eating disorders for Brazilian female athletes. The findings indicated the predictive equation:

[EAT-26 (score) $=-5.013+(0.121 \times \mathrm{BMI})+(0.115 \times \% \mathrm{G})+(0.102 \times \mathrm{SA}-$ TAQ-3) $-(0.013 \times B C A Q)+(0.141 \times B S Q)]$ with a $5 \%$ significance level

Many coaches and sports professionals stress the difficulty of identifying athletes susceptible to an eating disorder. The possibility of false answers is pointed out in psychometric tools that seek to assess the frequency of risk behaviors for eating disorders as one of these difficulties, for example, EAT-26. Although EAT-26 is an instrument with good psychometric properties, ${ }_{1}^{11}$ in the case of athletes, it is possible that they omit some responses due to the fear of being cut from the team. In this sense, it is necessary to develop new methods to screen athletes who are vulnerable to development of eating disorders.

The results of the this investigation indicated that chronological age and training regime did not related to risk behaviors for eating disorders. In fact, other studies have not shown a relationship between chronological age and frequency of risk of eating disorders. ${ }^{1,10}$ This demonstrates that there is no specific chronological age for an athlete to adopt risk behaviors for eating disorders as a strategy for reducing body weight. However, although there is still no scientific data to prove it, some researchers highlight that the training regime may be related to the frequency of risk behaviors for eating disorders. ${ }^{8,21}$ According to these researchers, young women at risk of developing eating disorders seem to seek the practice of sports with a strong training regime. Therefore, more research needs to be conducted to better clarify this relationship.

The findings of this study showed that BMI, \% F, body check and body dissatisfaction and drive for thinness related to risk behaviors for eating disorders and, therefore, were included in the regression model for the construction of the predictive equation. It should be noted that $43 \%$ of the variance in risk behaviors for eating disorders was explained by the predictors (BMI, \% F, body check and body dissatisfaction and drive for thinness). In addition, it should be noted that because all the predictors adhere to the model, it was possible to build an equation with the premise of predicting Brazilian female athletes' susceptibility to eating disorders.

Concerning the comparison between EAT-26 scores and the scores obtained in the predictive equation, the results showed no statistically significant difference. In this sense, the predictive equation is capable of reliably predicting EAT-26 scores. For example, an athlete who has the following characteristics (BMI $=25.00 \mathrm{~kg} / \mathrm{m}^{2}, \% \mathrm{~F}=25.00, \mathrm{SATAQ}-3=90$, $\mathrm{BCAQ}=10$ and $\mathrm{BSQ}=80$ ) will obtain a score of 21.21 regarding EAT-26, which indicates vulnerability to eating disorders, considering the cutoff established by Bighetti et al. ${ }^{11}$ Therefore, after SATAQ-3, BCAQ, BSQ being answered, together with the anthropometric assessment (BMI and\% F), it will be possible to track a female athlete who frequently uses risk behaviors for eating disorders.

Although this study indicates results with great practical applicability for sports coaches, it has limitations that deserve to be highlighted. The use of questionnaires is pointed out, as researchers emphasize that athletes may omit some behaviors/feelings. ${ }^{8}$ In addition, another limitation was the use of a doubly indirect method to assess \% F. According to some authors, ${ }^{5}$ using skinfolds can be limited to assess body composition. However, TME was calculated, which increases measurement reliability. Although there are limitations, it is believed that this investigation brings a new method to screen female athletes susceptible to developing eating disorders.

\section{CONCLUSIONS}

The results allowed concluding that the predictive equation is reliable to assess risk for eating disorders in Brazilian female athletes. The need to conduct new scientific investigations in order to assess the external validity of the created predictive equation is emphasized. In addition, it is necessary to create a risk predictive equation for eating disorders also regarding Brazilian male athletes.

All authors declare no potential conflict of interest related to this article 
AUTHORS' CONTRIBUTIONS: Each author made individual contributions to this manuscript. LSF: wrote the manuscript. SSA and MECF: performed the statistical analyses. SSA and MECF: performed the literature review and review of the manuscript, and contributed to the intellectual concept of the study.

\section{REFERENCES}

1. Bratland-Sanda S, Sundgot-Borgen J. Eating disorders in athletes: Overview of prevalence risk factors and recommendations for prevention and treatment. Eur J Sport Sci. 2012;1(1):1-10.

2. Durme KV, Goossens L, Braet C. Adolescent aesthetic athletes: A group at risk for eating pathology? Eat Behaviors. 2012;13(1):119-22

3. Fortes LS, Kakeshita IS, Almeida SS, Gomes AR, Ferreira MEC. Eating behaviours in youths: A comparison between female and male athletes and non-athletes. Scand J Med S Sports. 2014;24(1):e62-8.

4. Fortes LS, Neves CM, Filgueiras JF, Almeida SS, Ferreira MEC. Body dissatisfaction, psychological commitment to exercise and eating behavior in young athletes of aesthetic sports. Rev Bras Cineantropom Desempenho Hum. 2013;15(6):695-704.

5. Fortes LS, Almeida SS, Ferreira MEC. Anthropometric indicators of body dissatisfaction and inappropriate eating behaviors in young athletes. Rev Bras Med Esporte. 2013;19(1):35-9.

6. Fortes LS, Almeida SS, Ferreira MEC. A influência da periodização do treinamento sobre os comportamentos de risco para transtornos alimentares em nadadoras. Rev Educação Fís/UEM. 2014;25(1):127-34

7. Petrie T, Galli N, Greenleaf C, Reel J, Carter J. Psychological correlates of bulimic-symptomatology among male athletes. Psychol Sport Exercise. 2014;15(6):680-7.

8. Fortes LS, Ferreira MEC, Oliveira SMF, Cyrino ES, Almeida SS. A socio-sports model of disordered eating among Brazilian male athletes. Appetite. 2015;92:29-35.

9. Fortes $L S$, Carvalho PHB, Paes ST, Ferreira MEC. A checagem corporal possui relação com a restrição alimentar em atletas do sexo feminino? Rev Educação Fís/UEM. 2014;25(4):567-74.

10. El Ghoch M, Soave F, Cafugi S, Grave D. Eating disorders, physical fitness and sport performance: A systematic review. Nutrients. 2013;5(5):5140-60.

11. Bighetti F, Santos CB, Santos JE, Ribeiro RPP. Tradução e avaliação do eating attitudes test em adolescentes do sexo feminino de Ribeirão Preto, São Paulo. J Bras Psiquiatr. 2004;53(6):339-46.
12. Conti MA, Cordás TA, Latorre MRDO. Estudo de validade e confiabilidade da versão brasileira do body shape questionnaire (bsq) para adolescentes. Rev Bras Saúde Materna Infantil. 2009;9(3):331-8.

13. Di Pietro MC, Silveira DX. Internal validity, dimensionality and performance of the Body Shape Questionnaire in a group of Brazilian college students. Rev Bras Psiquiatr. 2009;31(1):21-4.

14. Kachani AT, Hochgar PB, Brasiliano S, Barbosa ALR, Cordás TA, Conti MA. Psychometric evaluation of the "Body Checking and Avoidance Questionnaire - BCAQ" adapted to brazilian portuguese. Eat Weight Disorders. 2011;16(2):293-9.

15. Amaral ACS, Cordás TA, Conti MA, Ferreira MEC. Equivalência semântica e avaliação da consistência interna da versão em português do Sociocultural Attitudes Towards Appearance Questionnaire-3 (SATAQ-3). Cad Saúde Pública. 2011;27(8):1487-97.

16. The Internacional Society for Advancement for Kineanthropometry [homepage on the Internet]. Australia: National Library of Australia [Acesso em Jul 2013]. Disponível em: http://www. isakonline.com.

17. Silva DAS, Pelegrini A, Pires-Neto CS, Vieira MFS, Petroski EL. O antropometrista na busca de dados mais confiáveis. Rev Bras Cineantr Desemp Hum. 2011;13(1):82-5.

18. Siri WE. The gross composition of the body. In: Tobias CA, Lawrence JH, editors. Advances in biological and medical physics. New York: Academic Press; 1956. p. 239-80.

19. Slaughter MH, Lohman TG, Boileau R, Hoswill CA, Stillman RJ, Yanloan MD. Skinfold equations for estimation of body fatness in children and youth. Human Biology. 1988;60(3):709-23.

20. Jackson AS, Pollock ML, Ward A. Generalized equations for predicting body density of women. Med Sci Sports. 1980;12(1):175-82.

21. Sundgot-Borgen J, Torstveit MK. Aspects of disordered eating continuum in elite high-intensity sports. Scand J Med Sci Sports. 2010;20(Supl 2):112-21. 